BMC

Evolutionary Biology

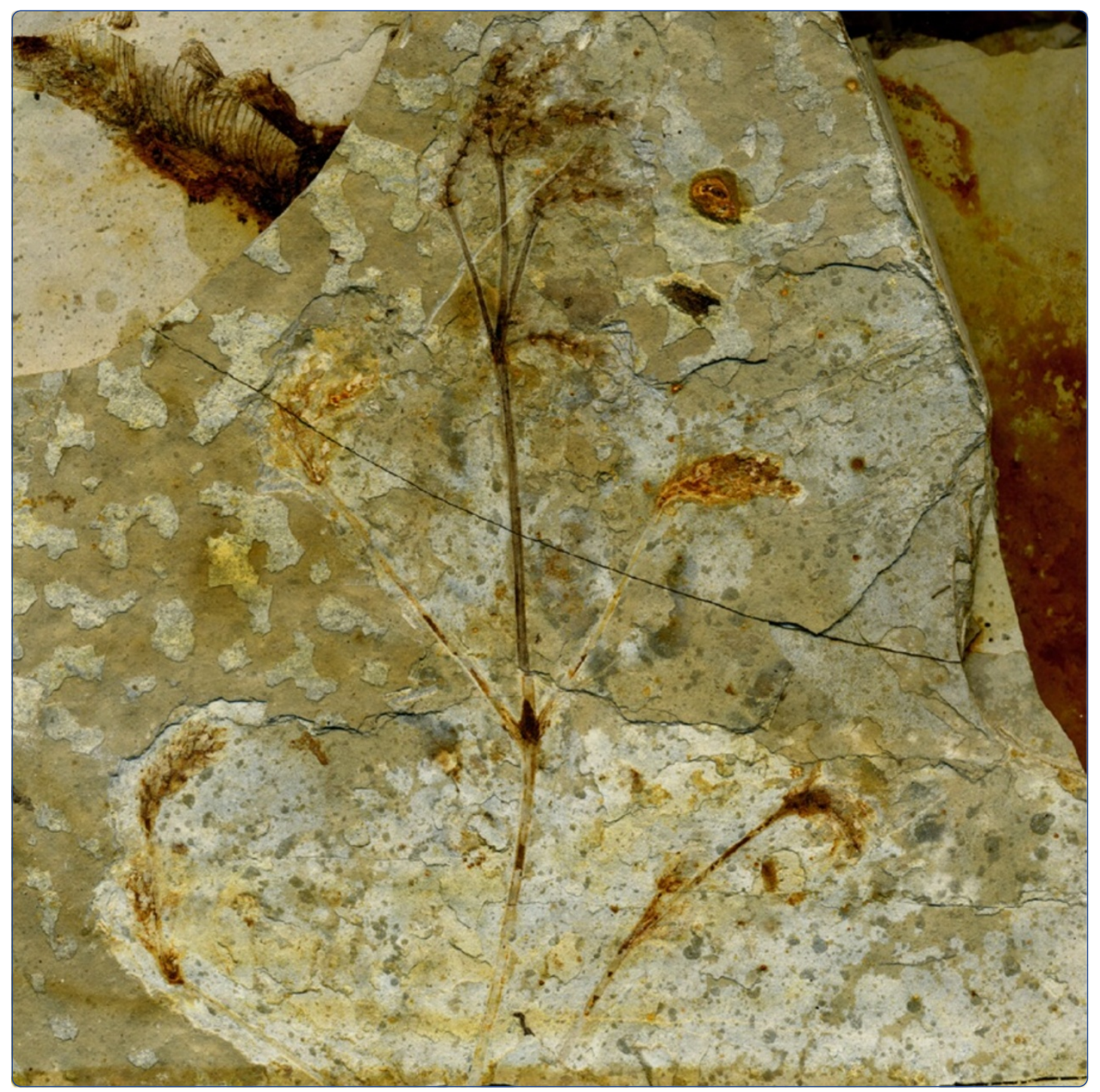

Chengia laxispicata gen. et sp. nov., a new ephedroid plant from the Early Cretaceous Yixian Formation of western Liaoning, Northeast China: evolutionary, taxonomic, and biogeographic implications

Yang et al. 


\title{
Chengia laxispicata gen. et sp. nov., a new ephedroid plant from the Early Cretaceous Yixian Formation of western Liaoning, Northeast China: evolutionary, taxonomic, and biogeographic implications
}

Yong Yang ${ }^{1}$, Longbiao Lin $^{2}$ and Qi Wang ${ }^{1 *}$

\begin{abstract}
Background: The extant Gnetales include three monotypic families, namely, Ephedraceae (Ephedra), Gnetaceae (Gnetum), and Welwitschiaceae (Welwitschia), all of which possess compound female cones that comprise a main axis and 1 to multiple pairs/whorls of bracts subtending a female reproductive unit or having lower pairs/whorls of bracts sterile. However, the evolutionary origin of such a reproductive architecture in Gnetales is controversial in the light of the competing anthophyte versus gnetifer hypotheses of seed plant relationships. Hence, macrofossils demonstrating the structure of compound female cones of the Gnetales should be important to decipher the early evolution of the order.

Results: A new ephedroid plant Chengia laxispicata gen. et sp. nov. is described from the Early Cretaceous Yixian Formation of western Liaoning, Northeast China. The fossil represents a part of a leafy shooting system with reproductive organs attached. The main shoot bears internodes and swollen nodes, from which lateral branches arise oppositely. Reproductive organs consist of female spikes terminal to twigs or axillary to linear leaves. Spikes are loosely arranged, having prominent nodes and internodes. Bracts of the spikes are decussately opposite and comprise 4-8 pairs of bracts. Each bract subtends an ellipsoid seed. Seeds are sessile, with a thin outer envelope and a distal micropylar tube.

Conclusions: Chengia laxispicata gen. et sp. nov. provides a missing link between archetypal fertile organs in the crown lineage of the Gnetales and compound female cones of the extant Ephedraceae. Combined with a wealth of Ephedra and ephedroid macrofossils from the Early Cretaceous, we propose a reduction and sterilization hypothesis that the female cone of the extant Ephedraceae may have stemmed from archetypal fertile organs in the crown lineage of the Gnetales. These have undergone sequentially intermediate links similar to female cones of Cretaceous Siphonospermum, Chengia, and Liaoxia by reduction and sterilization of the lower fertile bracts, shortenings of internodes and peduncles as well as loss of reproductive units in all inferior bracts. The basal family Ephedraceae including Ephedra of the extant Gnetales was demonstrated to have considerable diversity by the Early Cretaceous, so an emended familial diagnosis is given here. The Jehol Biota in Northeast China and adjacent areas contains a plethora of well-preserved macrofossils of Ephedra and ephedroids that show different evolutionary stages including primitive and derived characters of Ephedraceae, so Northeast China and adjacent areas may represent either the centre of origination or one of the centres for early diversification of the family.
\end{abstract}

Keywords: Biogeography, Chengia, Early Cretaceous, Ephedraceae, Ephedroid, Evolution, Female cone, Gnetales, Jehol biota, Reduction and sterilization hypothesis, Yixian Formation

\footnotetext{
* Correspondence: happyking@ibcas.ac.cn

'State Key Laboratory of Systematic and Evolutionary Botany, Institute of Botany, Chinese Academy of Sciences, 20 Nanxincun, Xiangshan, Beijing 100093, China

Full list of author information is available at the end of the article
} 


\section{Background}

The extant Gnetales, which are often classified into three monotypic families, namely, Ephedraceae Dumort., Gnetaceae Lindl., and Welwitschiaceae Markgr., have attracted extensive attention because of their enormous potential for understanding the origin of angiosperms and the phylogenetic relationships of seed plants due to the bisexual reproductive units that occasionally occur in Ephedra L. [1-4], vessels and broad leaves with reticulate venation present in Gnetum L. [5,6], ovules with multiple envelopes [7-10], and double fertilization [11-13]. This order now includes three relict genera Ephedra, Gnetum, and Welwitschia Hook. f., with a mutually exclusive geographic distribution $[6,7,9]$. Each of three genera possesses compound female cones that comprise a main axis and 1 to multiple pairs of opposite and decussate bracts or 1 to multiple whorls of ternately arranged bracts which usually subtend a female reproductive unit (Figure $1 \mathrm{a}-\mathrm{c}$ ). To date, there are primarily two competing hypotheses on the early evolution and phylogeny of the Gnetales [14-18] (Figure 1d). One hypothesis places the Gnetales into an anthophyte clade [19] using morphological data, which implies that the compound female cones of the Gnetales might be closely related to either flowers of angiosperms or fertile organs of Bennettitales, Erdtmanithecales, and other anthophytes [20-26] (Figure 1d, left). The other hypothesis nests the Gnetales within or closely related to conifers using molecular data, forming either gnepines or gnetifers or gnecups
[27-31] (Figure 1d, right), which infers that the compound female cones of the Gnetales and coniferophytes may be homologous. Therefore, the evolutionary origin and phylogenetic relationships of the Gnetales within seed plants remain controversial, and macrofossils especially regarding compound female cones should be important to decipher the early evolution of the order and their relationship with other seed plants.

The extant Ephedraceae (Ephedra) usually occupy a basal position in phylogenetic trees of the Gnetales (Figure 1d) while Gnetum and Welwitschia are more derived and are more closely related to each other than either is to Ephedra [14,17-23,27-33]. Ephedra has scalelike, linear and $2(-3)$ parallel-veined leaves which are often opposite and decussate at nodes and connate at the base into a sheath (e.g., E. equisetina Bunge, E. distachya L., E. sinica Stapf, E. pedunculata Engelm. ex S. Wats., and E. chilensis C. Presl), and ternate phyllotaxis is also not rare (e.g., E. intermedia Schrenk ex C. A. Mey., E. przewalskii Stapf, and E. ochreata Miers) $[4,6,7,9]$ (Figure 1a). In contrast, Welwitschia bears two opposite, enormous strap-like leaves with numerous parallel primary veins (and cross veins with apically oriented chevrons in cotyledons) [6,7,9] (Figure 1c), while Gnetum possesses petiolate, broad-laminar and reticulate-veined leaves that are arranged in opposite and decussate manner in most cases [6,7,9] (Figure 1b), and ternate phyllotaxis is also present (Yong Yang,

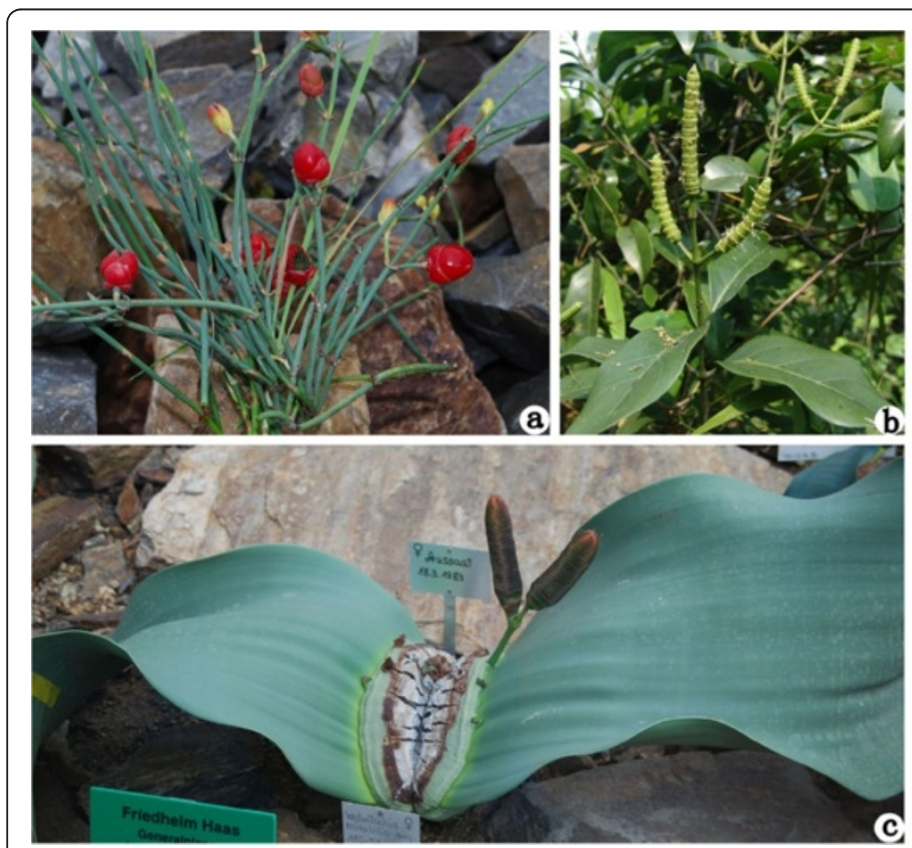

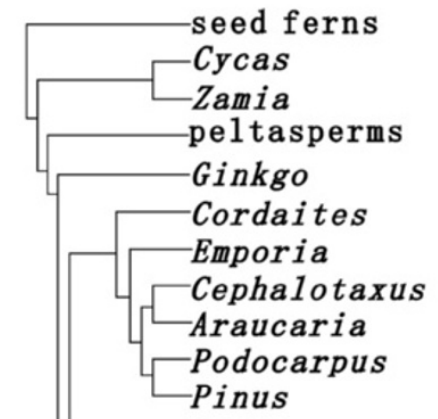
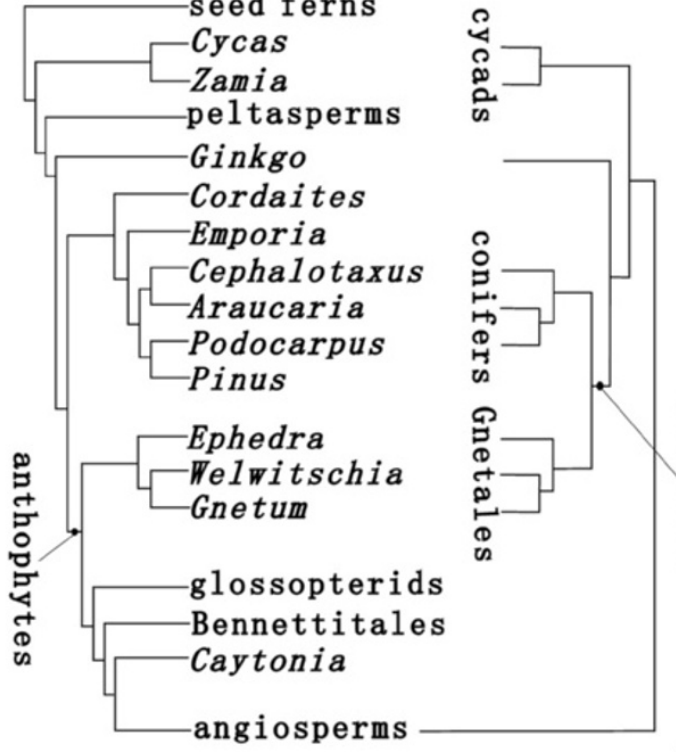

(d)

Figure 1 Three extant genera and phylogenetic relationships of the Gnetales. (a) Ephedra minuta Florin photographed at Chayu, Xizang (Tibet), China. (b) Gnetum parvifolium (Warb.) C.Y. Cheng ex Chun photographed at Fairy Lake Botanic Garden, Shenzhen, Guangdong Province, China. (c) Welwitschia mirabilis Hook. f. photographed at Dahlem Botanic Garden, Berlin, Germany. (d) Simplified phylogenetic trees of the Gnetales within seed plants (after [14]). Left: Gnetales are placed at the base of an anthophyte clade in the morphology tree. Right: Gnetales are embedded within conifers forming a gnetifer clade in the molecular tree. 
unpublished observations). Bracts and reproductive units of female cones of Ephedra and Welwitschia are opposite and decussate in most cases while those of Gnetum are usually whorled at nodes with the fusion of bracts into cupules and occasionally they are spirally arranged [34-36]. Both Gnetum and Welwitschia bear female cones with many whorls of fertile bracts while living Ephedra normally has only the uppermost whorl/pair of bracts fertile [37-39], rarely the inferior bracts subtending female reproductive units $[8,40]$, or hermaphroditic cones with the lower whorls of bracts bearing male reproductive units but the uppermost whorl possessing female reproductive units [41,42]. In addition, ovules of the Gnetales have 1-2 outer envelopes and the inner integument upwardly extended into a characteristic micropylar tube. Therefore, well-preserved female reproductive organs of the Gnetales may be easily recognized in the fossil record, and macrofossils of the basal family Ephedraceae are especially important in understanding the origin and phylogenetic relationships of the extant Gnetales.

So far, a variety of pre-Cretaceous macrofossils have been attributed to or compared with extant Gnetales (e.g., Palaeognetaleana auspicia Z.Q. Wang [43], Dechellyia gormanii Ash [9,44], Dinophyton spinosus Ash [9,45,46], Nataligma dutoitii J.M. Anderson et H.M. Anderson [9], Sanmiguelia lewisii Cornet [47,48], Archaestrobilus cupulanthus Cornet [49], Ephedrites sinensis Wu et al. and Ephedrites exhibens Wu et al. [50,51]), but their putative relationships to the Gnetales are not unequivocal due to lacking of synapomorphies recognized from the clade (e.g., compound female cones, whorled, opposite and decussate phyllotaxis in leaves, bracts, and bracteoles) and other detail (e.g., polyplicate pollen in situ) as Crane [52] previously suggested. Hence, the extant genera Ephedra, Gnetum, and Welwitschia, together with two Cretaceous genera Drewria Crane et Upchurch [53] and Eoantha Krassilov [54,55], were considered to form a crown group of the Gnetales [56] while those pre-Cretaceous genera were assigned to either stem-gnetaleans [9] or seed plants with uncertain affinities [48,52]. Recently, a wealth of additional Early Cretaceous macrofossils and mesofossils assignable to the crown-gnetaleans have been widely described from South Europe, Northeast China, Mongolia, North America, South America, and Australia [57], suggesting that three families Ephedraceae, Gnetaceae, and Welwitschiaceae of the extant Gnetales existed and diversified during at least the Early Cretaceous. Of all, macrofossils closely related to Welwitschia and Gnetum are very rare [58-60], but macrofossils and mesofossils (i.e., seeds) assignable to Ephedraceae or even to the extant Ephedra have been extensively reported [61-82]. These members of the Ephedraceae show a very high morphological diversity in both reproductive and vegetative organs across the world except for Africa and Antarctica. According to characteristics of female reproductive organs, Cretaceous ephedroid macrofossils can be classified into three groups, namely: (1) those with female cones bearing $1(-2$ ?) pairs of bracts with only the uppermost pair fertile, e.g., Ephedra carnosa Yang et Wang [61], E. archaerhytidosperma Yang et al. [62], E. hongtaoi Wang et Zheng [63] and E. verticillata Cladera et al. [64] as well as Alloephedra xingxuei Tao et Yang $[57,65,66]$ and two species of Gurvanella Krassilov 1982 [67-69] (= Chaoyangia Duan 1998 [70-73], non Chaoyangia Hou et Zhang 1993 [83] for an Early Cretaceous bird fossil also from Chaoyang District of Liaoning Province, Northeast China; for nomenclatural discussions see $[57,67,69,84])$; (2) those with female cones possessing multiple whorls of fertile bracts each subtending a female reproductive unit, e.g., numerous species of Liaoxia Cao et Wu 2006 [74] (= Ephedrites Göppert et Berendt 1845 [75], non Ephedrites Saporta 1891[67,76]); and (3) those that have ovules surrounded by envelopes lacking supporting bracts and directly attached on the peduncles, e.g., Siphonospermum simplex Rydin et Friis [77]. Therefore, the basal gnetalean family Ephedraceae, including the extant genus Ephedra, was demonstrated to have considerable diversity by the Early Cretaceous.

In this paper, we study a new ephedroid macrofossil from the Early Cretaceous Yixian Formation of western Liaoning Province, Northeast China, and name it Chengia laxispicata gen. et sp. nov.. Our new plant bears a comparatively complete, leafy shooting system with loose female spikes that allow us to discuss the evolution of female cones of the Ephedraceae. We also consider the taxonomic and biogeographic implications of our findings on the basis of abundant ephedroid macrofossils from the Early Cretaceous Jehol Biota of Northeast China and adjacent areas.

\section{Results}

\section{Description of the specimens}

The macrofossils presented here based on information from the part and counterpart of a single well-preserved and articulated specimen (PE 2012041619A, B) that represents part of a leafy shooting system with reproductive organs attached (Figure 2a-b). The shooting system represents the distal part of the plant and is preserved at least $10.2 \mathrm{~cm}$ long, and the shoot is ca. $(0.21-)$ ) $0.53-1.06$ $(-1.2) \mathrm{mm}$ wide. The main shoot is slightly curved, with nodes and internodes. Nodes are swollen, from which the lateral branches arise oppositely (Figure $2 \mathrm{a}-\mathrm{b}$, Figure $3 \mathrm{a}$ ). Internodes are $2-3.8 \mathrm{~cm}$ long or more, taper toward the distal region and have numerous fine, longitudinal striations, in which ridges and furrows are discernible (Figure $3 \mathrm{~b}$ ). The main shoot branches at least 4 times. Lateral branches are stretched upwards at $15-70^{\circ}$ and do not ramify or dichasially ramify once to twice. Leaves, 
which subtend lateral branches, are linear, about $1.2 \mathrm{~cm}$ long, but the venation is indiscernible (Figure 3a). Foliar structures at the base of spikes are specialized into involucres which are linear, about $1.3 \mathrm{~mm}$ long, approximately perpendicular to the shoot at the proximal part and slightly curved inward at the distal part (Figure 3c). Spikes are terminal to twigs or are axillary to leaves, $1-2.6 \mathrm{~cm}$ long and 2-4 $\mathrm{mm}$ wide, and mature acropetally (Figure 2a-b). Spikes are loosely arranged at the distal end of the main shoot, but more compact on the basal lateral branches (Figure 2a-b). Those loosely arranged spikes are noticeable in having prominent nodes and internodes (Figure 3c). Nodes are swollen, and each node gives rise to two opposite and spreading bracts. Internodes are approximately $1-2 \mathrm{~mm}$ long, acropetally becoming successively shorter and shorter (Figure 3c). Bracts of spikes are decussately opposite and comprise 4-8 pairs that are linear in lateral view (Figure $3 \mathrm{~d}-\mathrm{g}$ ). Each bract subtends an ellipsoid seed, about 1.85-2.23 $\mathrm{mm}$ long and 1.05-1.16 mm wide. Seeds are sessile, with a thin outer envelope and a distal, hollow micropylar tube, about 0.34-0.75 mm long (Figure $3 \mathrm{~d}-\mathrm{g}$ ). Spikes of this plant are all female, which are oriented toward one side of the shooting system and appear to have been flexible rather than rigid. A reconstruction of this plant is given here (Figure $4 \mathrm{a}-\mathrm{b}$ ).

\section{Discussion}

\section{Identity and affinity}

The fossil specimens studied here obviously possess opposite organographic features, including opposite lateral branches, leaves as well as decussately opposite bracts and enveloped seeds, all of which conform to the diagnostic and synapomorphic features of the Gnetales [6,7,9, $19,32,52,85,86]$. Hence this plant can be readily classified into the Gnetales, and its linear leaves and decussately opposite bracts that comprise female spikes resemble those of the ephedroids. However, the decussately opposite bracts and loose female spikes with clear nodes and internodes are noticeably different from all known ephedroid fossils $[52,57]$ and extant Ephedra that bears female cones usually having 2-13 pairs/whorls of cone bracts but with only the uppermost pairs/whorls of bracts being fertile $[4,6,7,9]$. Therefore, the fossils presented here do not conform to the generic circumscription of Ephedra and require a new name for which we institute Chengia laxispicata gen. et sp. nov. and place it within the ephedroid Gnetales (See Conclusion-Systematics).

\section{The evolution of female cones in Ephedraceae}

Previous morphological, anatomical, ontogenetic, and molecular studies supported a reduction hypothesis that female cones of the extant Ephedraceae may have stemmed from a loosely arranged, multi-axial, reproductive organs homologous to the Late Palaeozoic Cordaitales and Permian-Triassic coniferophytes $[4,6,8,15,17,35,36,38-40$, 87-94]. With shortening of internodes of the reproductive multi-axial shoot system, both the primary and secondary shoots of Ephedraceae, to some extent, may have experienced a series of structural reductions and finally given rise to compact female cones in extant Ephedra [4,8,87,89]. Hence, female cones similar to laxly arranged reproductive
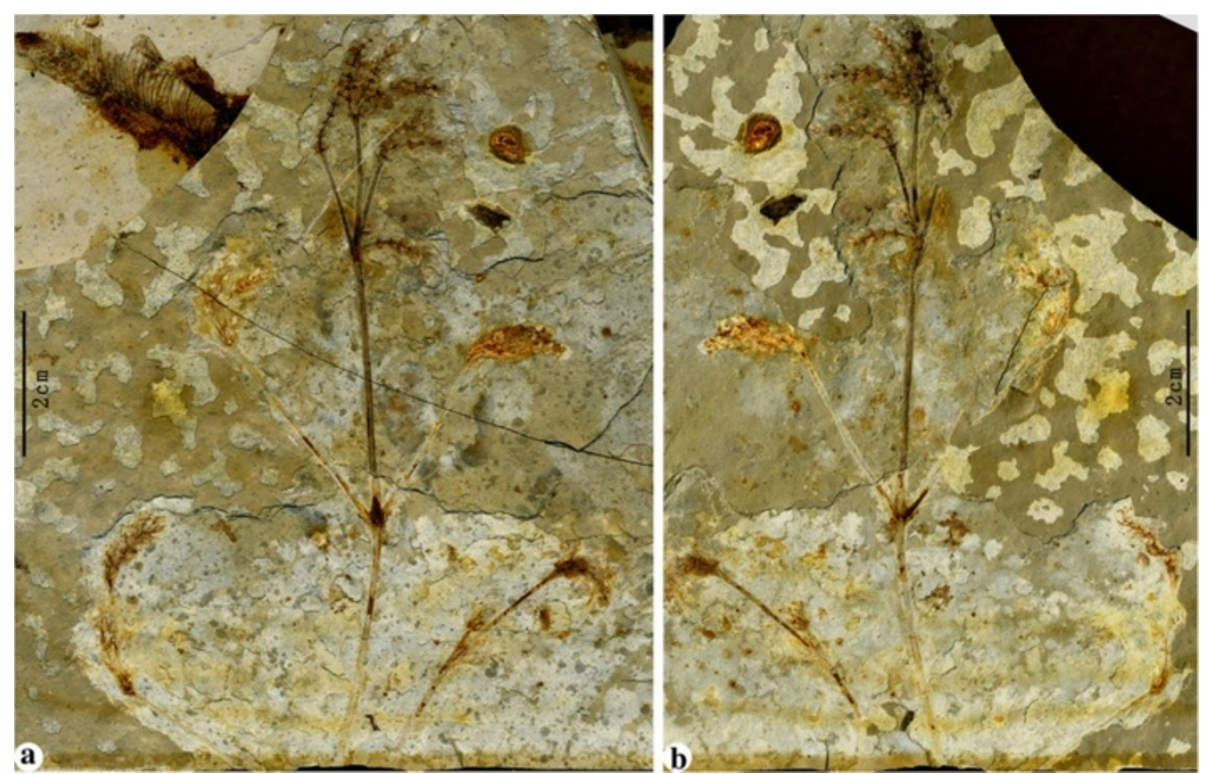

Figure 2 The general morphology of Chengia laxispicata gen. et sp. nov.. Holotype: PE 2012041619A, B. A gathering of part (a) and counterpart (b) specimens. Note that there is a piece of Lycoptera fish fossil exposed on the bedding plane below this plant-bearing bed. 


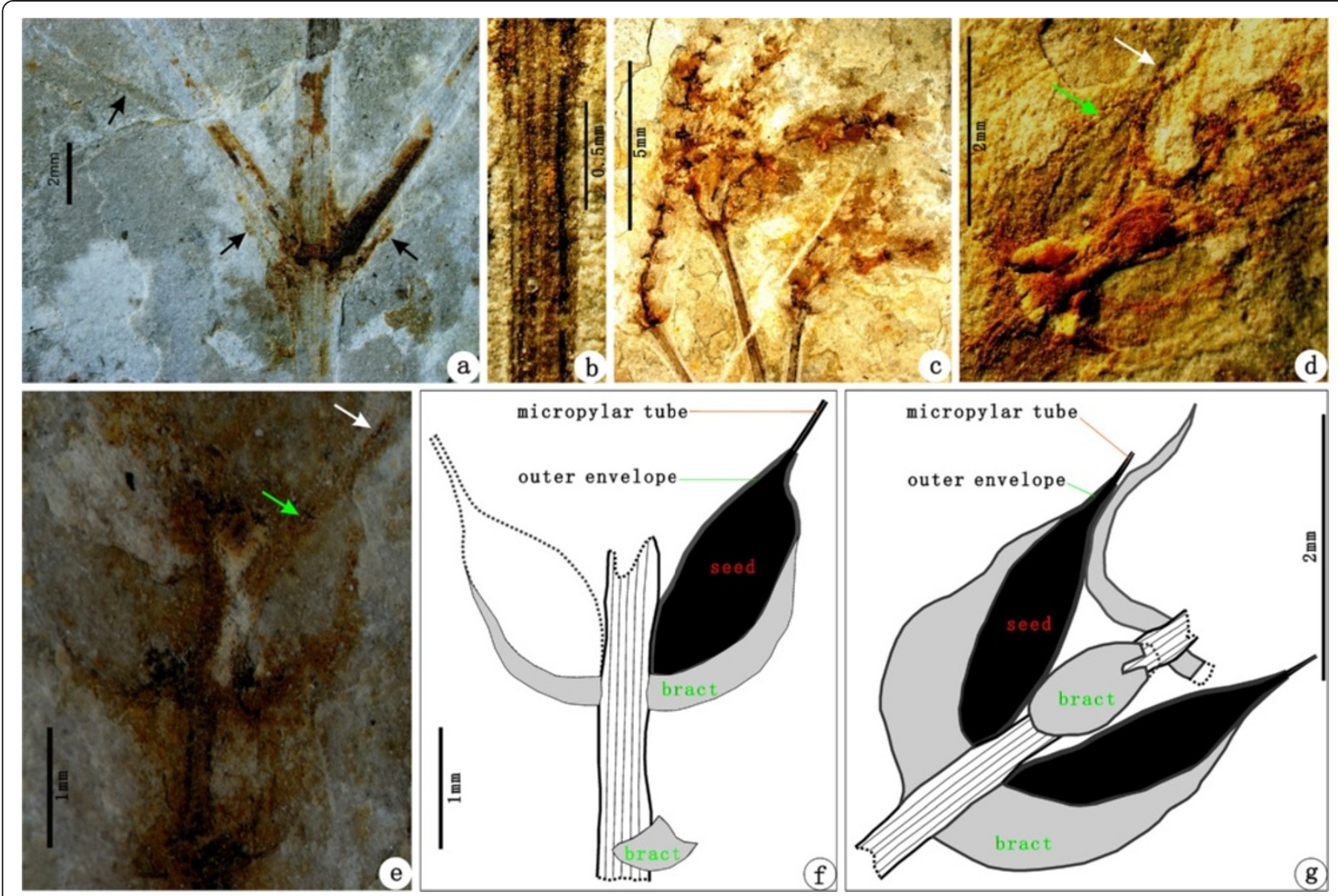

Figure 3 Morphological detail of Chengia laxispicata gen. et sp. nov.. (a) A node showing the opposite branching pattern and subtending elongate-linear leaf (arrows). (b) An internode showing the fine longitudinal striations. (c) Terminal female spikes with the loosely arranged bracts and prominent internodes. (d-e) The morphology of female reproductive units. Green arrows refer to an enveloped seed axillary to a bract. White arrows refer to a thin, hollow micropylar tube. (f- $\mathbf{g})$ The camera lucida drawing of partial spikes in (e) and (d), showing the decussate and opposite fertile bracts.

shooting systems would represent more primitive organizations than those resembling to compact reduced female cones of the extant Ephedraceae. Our new fossil Chengia laxispicata gen. et sp. nov. bearing loose female spikes appears to be a missing link to the extant Ephedraceae with compact cones.

Early Cretaceous macrofossils have provided diverse characteristics of female reproductive structures. Ovulate cones of Ephedra carnosa [61], E. archaeorhytidosperma [62], E. hongtaoi [63], Gurvanella dictyoptera Krassilov and G. exquisita Sun et al. [67-69,80] from the Early Cretaceous Jehol Biota of Northeast China and adjacent areas bear either $1(-2$ ?) pairs or 1 whorl of bracts enclosing $1-3$ seeds, effectively demonstrating the same pattern as modern Ephedra that possesses only the uppermost one pair/whorl of fertile bracts. Siphonospermum simplex has linear leaves, opposite phyllotaxis, and ovules with exposed micropylar tubes and surrounded by envelopes, which are attached directly on the peduncles, so these ephedroid features may be plesiomorphic in the Gnetales [77]. Female spikes of Liaoxia have multiple whorls of fertile bracts each subtending a female reproductive unit (or seed) (referring to Liaoxia robusta Rydin et al. [74]), which provide palaeobotanical evidence for the previous morphological-evolutionary interpretation that the archetypal female cone of Ephedraceae may be compound, with multiple-whorled fertile bracts.

Our new ephedroid fossil-genus Chengia markedly differs from both extant and fossil species of Ephedra by the female cone bearing multiple (4-8) pairs of fertile bracts. It is different from Siphonospermum by the female reproductive unit possessing subtending bracts. Chengia also differs from Liaoxia in having loosely arranged female cones. The female spikes of Chengia have evident nodes and internodes showing similarity to the supposed laxly arranged reproductive shoot system of ancient ancestors, so such female cones in Ephedraceae are more primitive than those of Liaoxia and other ephedroid fossils (e.g., Alloephedra, Gurvanella, and Ephedra).

Chengia together with other macrofossils from the Early Cretaceous Yixian Formation of Northeast China 


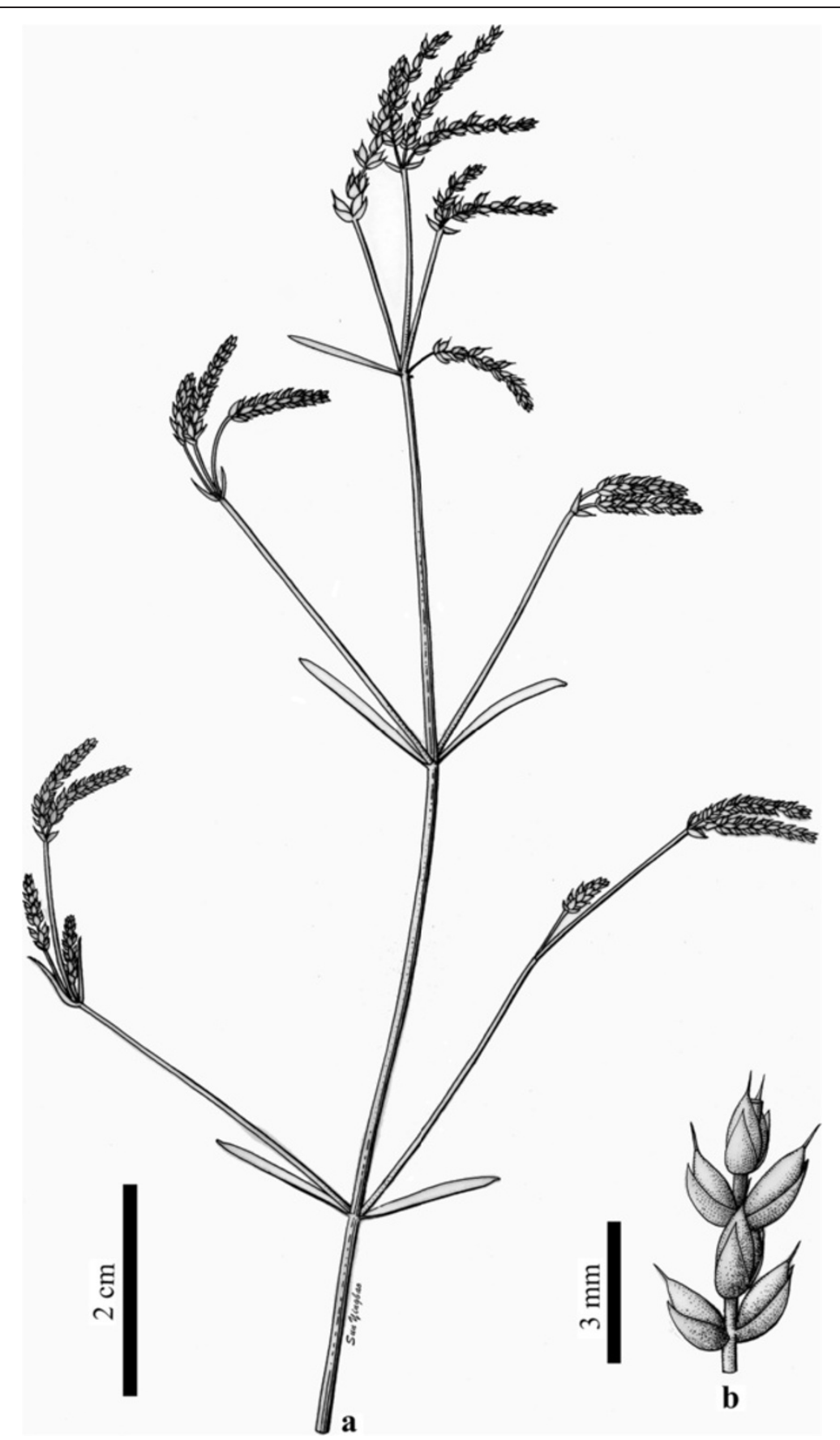

Figure 4 A reconstruction of Chengia laxispicata gen. et sp. nov.. (a) The general morphology of Chengia laxispicata. (b) The morphology of a partial female reproductive spike.

give instrumental clues to the morphological transformation of cone bracts in Ephedraceae. According to current phylogenetic trees of the Gnetales [14,17,18] (Figure 1d), the ancestral form of the order is far more likely to bear compound female cones regardless of the anthophyte hypothesis or gnetifer hypothesis. Here, we propose a reduction and sterilization hypothesis that the female cone of Ephedra is derived from that of Siphonospermum, Chengia, and Liaoxia by a series of changes that include reduction and sterilization of lower fertile bracts, shortenings of internodes and peduncles, loss of reproductive units in all inferior bracts, and retains only the uppermost pair/whorl of bracts fertile (Figure 5). 


\section{Conclusion}

This ephedroid plant Chengia laxispicata gen. et sp. nov. described from the Early Cretaceous Yixian Formation of Northeast China provides a missing link between archetypal fertile organs of the crown lineage of the Gnetales and compound female cones of the extant Ephedraceae. Based upon a plethora of Ephedra and ephedroid macrofossils from the Early Cretaceous, we propose a reduction and sterilization hypothesis that the female cone of the extant Ephedraceae may have stemmed from archetypal fertile organs of the crown lineage of the Gnetales, which have undergone sequentially intermediate links similar to female cones of Cretaceous Siphonospermum, Chengia, and Liaoxia by a series of transformations that include reduction and sterilization of the lower fertile bracts, shortenings of internodes and peduncles, loss of reproductive units in all inferior bracts. The basal family Ephedraceae including Ephedra of the extant Gnetales was demonstrated to have considerable diversity by the Early Cretaceous, so an emended familial diagnosis is given here. The Jehol Biota in Northeast China and adjacent areas contains a plethora of well-preserved macrofossils of Ephedra and ephedroids that show different evolutionary stages including primitive and derived characters of Ephedraceae, so Northeast China and adjacent areas may represent either the centre of origination for the family or its centre of early diversification.

\section{Systematics}

Gnetales Luerss. 1879

Ephedraceae Dumort. 1829, emend.

Type: Ephedra L. 1753, Sp. Pl. 1040.

Familial diagnosis emended (based on previous work [7,95-99] and present study)

Dioecious (rarely monoecious) shrubs, sub-shrubs, small tree, climbers, or sometimes perennial herbs. Shoots are profusely and dichasially branched and have many nodes; nodes are usually swollen, sometimes branches are whorled at nodes due to extremely reduction of internodes or alternate on account of suppression of the opposite branch; internodes of twigs possess many fine striations. Leaves are opposite and decussate or ternately whorled at nodes, linear and free to basally connate into a sheath but apices acute and triangular. Leaves are parallel veined, with $2(-3)$ veins. Reproductive organs are usually unisexual but hermaphroditic cones occasionally occur. Male cones are terminal to twigs, or pedunculate, or sessile and axillary to leaves, or clustered at nodes, bear multiple pairs/whorls of bracts each of which enclose an axillary male reproductive unit. The male reproductive unit is a shortened shoot and usually consists of a pair of

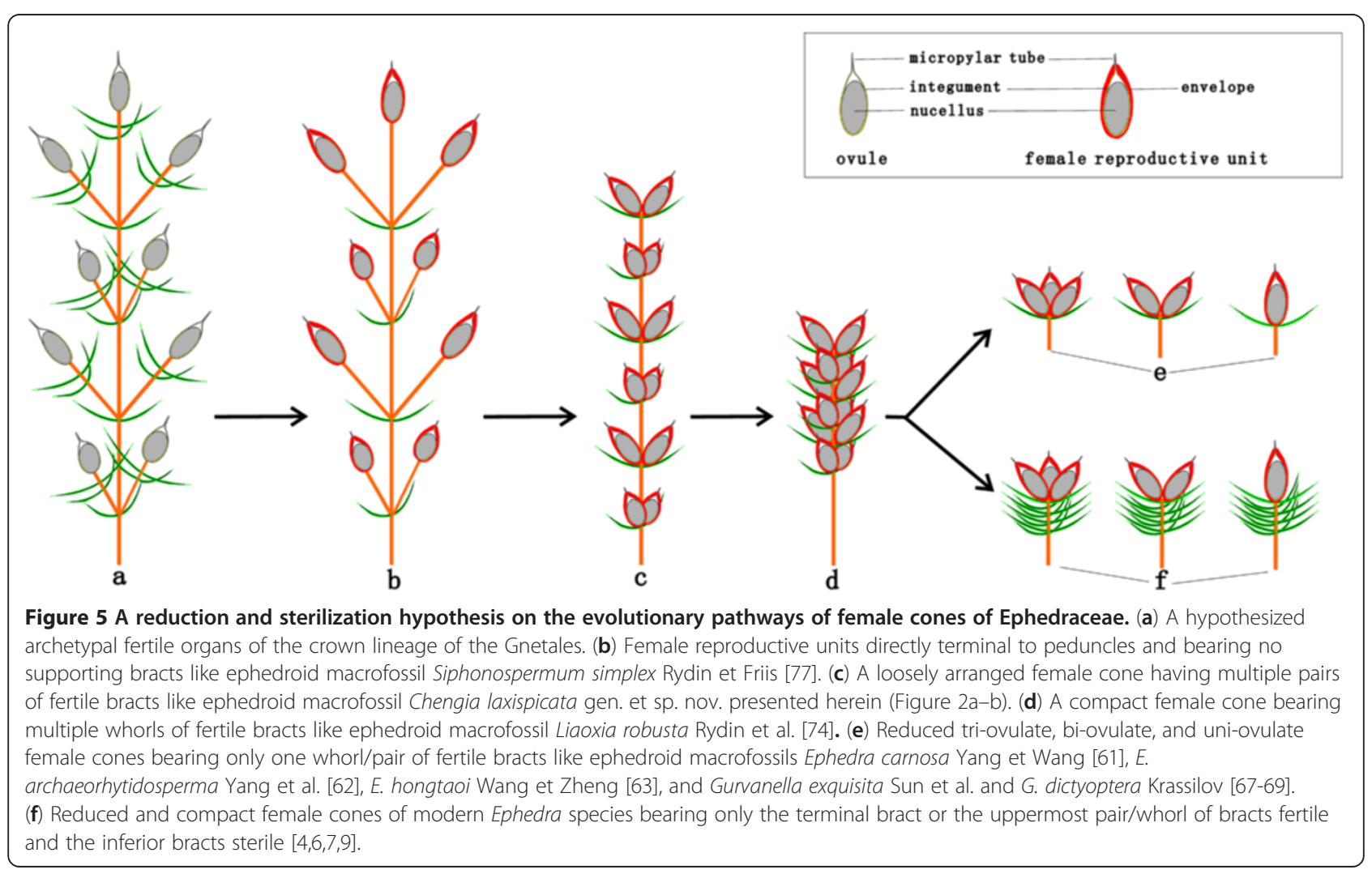


bracteoles enclosing 1 microsporangiophore. The microsporangiophore is fused or distally furcated, and terminated by $2-8$ synangia. The synangium is sessile to pedicellate, consists of 2-3 microsporangia, the latter opening by horizontal slits. At maturity, the microsporangiophore is elongated outside the bracteoles and terminated by a few free or fused synangia which produce polyplicate pollen bearing longitudinal ridges and furrows. The female reproductive units (FRUs) or compound female cones are directly terminal to twigs, or pedunculate or sub-sessile or sessile at nodes. The compound female cones if present are trimerous or bimerous, bear 1 to multiple whorls/pairs of leaf-like or specialized bracts, each subtending a female reproductive unit, or only the uppermost whorl/pair of bracts being fertile and the inferior whorls/pairs of bracts becoming sterile. Cone bracts are sometimes modified into dry and membranous, or dry and coriaceous, or fleshy and colourful. Seeds bear an outer envelope and an inner integument which usually extends upward and passes through the opening of the outer envelope, forming a thin and hollow micropylar tube. Micropylar tubes varying in length and shape, $0.2-4 \mathrm{~mm}$ long, straight, curved or coiled.

\section{Remarks}

In 1829, the family Ephedraceae was instituted by the Belgian botanist Barthélemy-Charles Dumortier (1797-1878) [100], who only gave a brief familial diagnosis "ovaire supère stylifère; écailles opposes; ovaire monogyne". In modern plant taxonomy, the Ephedraceae are usually characterized by features of the sole extant Ephedra [7,95-99]. However, abundant ephedroid fossil plants from the Early Cretaceous have increasingly broadened our understanding of the circumscription and character variation of the family, so an emended familial diagnosis is provided here. The key diagnoses (Figure 5) of Ephedraceae include enveloped ovules with extruded micropylar tubes (i.e., female reproductive unit), linear leaves opposite and decussate or ternately whorled and having 2-3 parallel veins. In light of the present study, Ephedraceae sensu lato contain Ephedra L. with ca. 50 living species, 4 macrofossil-species (i.e., E. carnosa Yang et Wang, E. archaeorhytidosperm Yang et al., E. hongtaoi Wang et Zheng, E. verticillata Cladera et al. [61-64]), and 2 seed fossil-species (i.e., E. portugallica Rydin et al. and E. drewriensis Rydin et al. [82]) as well as ephedroid macrofossils Alloephedra Tao et Yang $[57,65,66]$, Gurvanella Krassilov [67-69], Liaoxia Cao et Wu [74], Siphonospermum Rydin et Friis [77], Leongathia Krassilov et al. [78], Amphiephedra Miki [101], and Chengia gen. nov. presented herein, indicating higher generic diversity through time. Early Cretaceous strata of Northeast China contain a plethora of well-preserved macrofossils (that sometimes are comparatively complete individuals) of Ephedra and ephedroids that show different evolutionary stages including primitive and derived characters of Ephedraceae, and in this respect Northeast China and adjacent areas that yield the famous Jehol Biota [102-112] might represent either the centre of origination or one of centres for early diversification of the family.

Chengia laxispicata Y.Yang, L.B.Lin et Q.Wang gen. et sp. nov. (Figures 2, 3 and 4).

\section{Etymology}

The generic name "Chengia" is dedicated to the late eminent botanist Cheng Wan-Chun (1904-1983) (Chinese Academy of Forestry, Beijing) who has made enormous contributions to the taxonomy of gymnosperms; the specific epithet "laxispicata", stemming from the Latin "laxus" + "spicatus", refers to the loosely arranged female spike which is a conspicuous feature of this fossil-species.

\section{Generic and specific diagnosis}

Reproductive shoots branch oppositely at swollen nodes. Internodes bear numerous longitudinal striations. Leaves that subtend lateral branches are long and linear. Female spikes are terminal to twigs or are subtended by the leaf, possessing multiple pairs of loosely arranged female reproductive units. Nodes and internodes of female spikes prominent. Female reproductive units consist of decussately opposite seeds and subtending bracts. Seeds enveloped, with distal micropylar tube.

Description: (see Results-Description of the specimens).

\section{Holotype}

PE 2012041619A, B (Figure 2a-b) (designated here. Part and counterpart specimens).

\section{Type locality}

Dawangzhangzi Village, Songzhangzi Town, Lingyuan City, Chaoyang District, Liaoning Province, China (Figure 6, left).

\section{Stratigraphic horizon and age}

Dawangzhangzi Bed in the middle part of the Yixian Formation or Xinfangzi Bed in the lower part of the Yixian Formation (the Early Aptian-earliest Late Aptian of the Early Cretaceous) (see Methods as follows).

\section{Repository}

Chinese National Herbarium (PE), Institute of Botany, Chinese Academy of Sciences, Beijing, China.

\section{Remarks}

The plant-bearing beds at Dawangzhangzi Village (Figure 6, left), Lingyuan City, Chaoyang District, Liaoning Province, Northeast China have been known since the 1930s. Fossil fish Lycoptera jeholensis Grabau, monocotyledonous plants Potamogeton jeholensis Yabe et Endô, Potamogeton ? sp., gymnosperms Schizolepis jeholensis 
Yabe et Endô and Czekanowskia rigida Heer were first reported from this Early Cretaceous locality [113,114]. Subsequently, Potamogeton jeholensis was reclassified as another angiosperm Ranunculus jeholensis (Yabe et Endô) Miki [101] or an ephedroid plant Ephedrites chenii (Cao et $\mathrm{Wu}$ ) Guo et X.W. Wu $[67,76]$ (correctly cited as Ephedrites cheniae Guo et X.W. Wu $[57,75])$, which is synonymous with Liaoxia cheniae (Guo et X. W. Wu) Cao et S. Q. Wu [74]. Moreover, Miki [101] described a new ephedroid plant Amphiephedra rhamnoides Miki from this locality, which is different from our new plant Chengia laxispicata gen. et sp. nov. in bearing "verticillate, scaly leaves on the lateral branches that look more like short shoots" (translated from the original description in Japanese by Atsushi Yabe, 2012, personal communication).

Adjacent to Dawangzhangzi Village of Lingyuan City, an ephedroid plant Ephedrites? elegans Sun et Zheng [67] was described from the Jianshangou Bed in the lower part of the Yixian Formation of Huangbanjigou Village (Figure 6, middle), Beipiao City, Chaoyang District, Liaoning Province, Northeast China. Ephedrites? elegans (specimens examined: PB 19175A, B) also bears loosely arranged spikes with clear nodes and internodes, but it differs from our new plant Chengia laxispicata gen. et sp. nov. in having possibly $3-5$ bracts per whorl in spikes (see original authors' description) [67]. Another superficially similar specimen was also reported from the Early Cretaceous Lycoptera beds of Manlaj, eastern Gobi in Mongolia, which Krassilov called "Potamogetonlike spike" bearing 2 or 3 nutlets per node (see original author's description) [68].

\section{Methods}

The specimens used in this study were collected from Dawangzhangzi Village (Figure 6, left), Lingyuan City, Liaoning Province, Northeast China and occur as part and counterpart on a slab of light grey to yellowish, finely laminated siltstone (Figure $2 \mathrm{a}-\mathrm{b}$ ). The plant fossils are preserved as compressions/impressions only with little organic material remaining, and a piece of Lycoptera fish fossil is also present on the same slab. The stratum yielding the present specimens belongs to the informally named "Lycoptera Beds" (i.e., Xinfangzi Bed), which corresponds to the "Jianshangou Bed" in the lower part of the Yixian Formation of Huangbanjigou Village, Beipiao City, Liaoning Province, Northeast China [67] (Figure 6). However, some palaeontologists [104-107] designated the statum as the Dawangzhangzi Bed, which corresponds to the middle part of the Yixian Formation, overlying the Jianshangou Bed. On the basis of radiometric dating, the Jianshangou and Dawangzhangzi Beds of the middle-lower Yixian Formation are given a geological

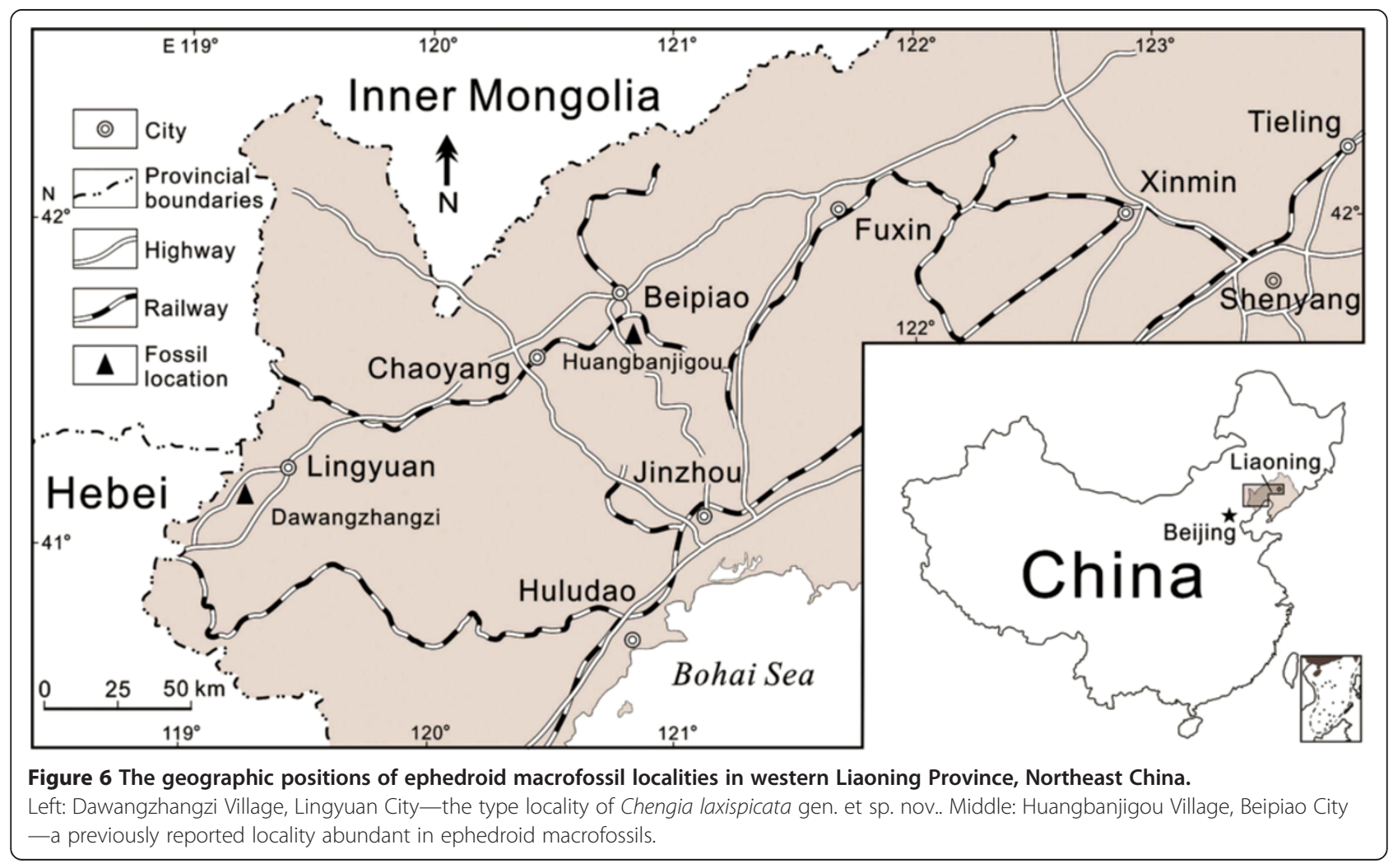


age ranging from ca. 125 to $120 \mathrm{Ma}$ [104-112], corresponding to the Early Aptian-earliest Late Aptian of the Early Cretaceous in the newest Geologic Time Scale (GTS 2012) [115].

The fossils (Figures 2 and 3) were photographed with digital cameras (Nikon D700 and Panasonic DMC-FZ30) and under a microscope (Nikon Eclipse E600). Previously published ephedroid macrofossils from the lower part of the Yixian Formation of Huangbanjigou Village (Figure 6, middle), Beipiao City, Liaoning Province, Northeast China were examined at the Institute of Botany (CAS), Beijing (specimens prefixed PE), and Nanjing Institute of Geology and Palaeontology (CAS), Nanjing (specimens prefixed PB). The modern gnetalean plants (Figure $1 \mathrm{a}-\mathrm{c}$ ) were photographed respectively at Chayu (Tibet, China), Shenzhen Fairy Lake Botanic Garden (Guangdong, China), and Dahlem Botanic Garden (Berlin, Germany). Simplified phylogenetic trees (Figure 1d) of the Gnetales within seed plants were adapted from the literature [14]. The illustrations (Figure $4 \mathrm{a}-\mathrm{b}$ ) were drawn using a pointed pen and black inks [116]. The illustrations (Figures 5 and 6) were drawn using CorelDraw 10.0 programme (Chinese edition, Tianlong Corporation, Beijing).

To comply with requirements of the International Code of Nomenclature for algae, fungi, and plants (Melbourne Code) [117], we have deposited paper copies of this article in libraries at the Institute of Botany, Chinese Academy of Sciences, Beijing; Peking University, Beijing; the Institute of Vertebrate Paleontology and Paleoanthropology, Chinese Academy of Sciences, Beijing; Nanjing Institute of Geology and Palaeontology, Chinese Academy of Sciences, Nanjing; Kunming Institute of Botany, Chinese Academy of Sciences, Kunming; Sun Yat-sen University, Guangzhou; Lanzhou University, Lanzhou; Jilin University, Changchun; Shenyang Normal University, Shenyang; National Museum of Natural History, Smithsonian Institution, Washington, D.C.; Indiana University, Bloomington; University of California Museum of Paleontology, Berkeley; Florida Museum of Natural History, the University of Florida, Gainesville; Peabody $\mathrm{Mu}-$ seum of Natural History, Yale University, New Haven; Ohio University, Athens; the University of Kansas, Lawrence; the University of Birmingham, Birmingham; National Museum Wales, Cardiff, UK; the Swedish $\mathrm{Mu}-$ seum of Natural History, Stockholm; Geological Institute, ETH, Zürich; Charles University, Prague; Institute of Evolution, University of Haifa, Israel; the Staatliche Museum für Naturkunde, Stuttgart; Hungarian Natural History Museum, Budapest; Chuo University, Tokyo; National Museum of Nature and Science, Tsukuba, Japan; National Institute of Carpology, Moscow; Far Eastern Geological Institute, Far Eastern Biological and Soil Institute, the Academy of Sciences of the USSR, Vladivostok; The University of Adelaide, Adelaide, Australia.

\section{Competing interests}

The authors declare that they have no competing interests.

\section{Authors' contributions}

YY and QW conducted photographing specimens, data analyses, and evolutionary interpretations and wrote the manuscript. LBL collected the type specimens and participated in discussions. QW arranged the figures and formatted the text. All authors read and approved the final manuscript.

\section{Acknowledgements}

We greatly thank two anonymous reviewers for helpful comments on the manuscript. Dr. Shi Gongle and Mr. Yuan Daojun, Nanjing Institute of Geology and Palaeontology, Chinese Academy of Sciences (CAS), Nanjing for access to the specimen collections. Dr. Wang Kang, Beijing Botanic Garden, Mr. Ma Xintang and Liu Bing, Institute of Botany, CAS, Beijing for sending the images of Welwitschia, Gnetum, and Ephedra. Mr. Sun Yingbao, Institute of Botany, CAS, Beijing for drawing the reconstruction of this fossil plant. Mr. Zong Ruiwen, China University of Geosciences, Wuhan for graphing the map. Dr. Harufumi Nishida, Chuo University, Tokyo, Dr. Atsushi Yabe, National Museum of Nature and Science, Tsukuba, Dr. Valentin Krassilov, Institute of Evolution, University of Haifa, Mrs. Anna Pavlova, National Institute of Carpology, Moscow, Dr. Eugenia Bugdaeva, Far Eastern Biological and Soil Institute, the Academy of Sciences of the USSR, Vladivostok, and Dr. Wang Shijun, Institute of Botany, CAS, Beijing for providing us with some key references. Dr. Atsushi Yabe, Mr. Makoto Ishimura, Chigasaki City for the linguistic assistance in Japanese. This work was supported by the National Natural Science Foundation of China (nos. 30970177, 31270238, 40972015, and 40830209), the State Key Laboratory of Systematic and Evolutionary Botany, CAS (no. 56176G1044), and the State Key Laboratory of Palaeobiology and Stratigraphy, Nanjing Institute of Geology and Palaeontology, CAS (no. 123106) to QW and YY.

\section{Author details}

${ }^{1}$ State Key Laboratory of Systematic and Evolutionary Botany, Institute of Botany, Chinese Academy of Sciences, 20 Nanxincun, Xiangshan, Beijing 100093, China. ${ }^{2}$ China Railway Group Limited, 69 Fuxing Road, Beijing, 100039, China.

Received: 14 December 2012 Accepted: 20 March 2013

Published: 27 March 2013

\section{References}

1. Arber EAN, Parkin J: Studies on the evolution of the angiosperms, the relationship of the angiosperms to the Gnetales. Ann Bot 1908, 22:489-515.

2. Mehra PN: Occurrence of hermaphrodite flowers and the development of the female gametophyte in Ephedra intermedia Schrenk et Mey. Ann Bot 1950, 14:165-180.

3. Endress PK: Structures and function of female and bisexual organ complexes in Gnetales. Int J Plant Sci 1996, 157(6 suppl.):S113-S125.

4. Yang Y: Systematics and evolution of Ephedra L. (Ephedraceae) from China, Ph.D. thesis. Beijing: Institute of Botany, Chinese Academy of Sciences; 2002.

5. Muhammad AF, Sattler R: Vessel structure of Gnetum and the origin of angiosperms. Am J Bot 1982, 69:1004-1021.

6. Gifford EM, Foster AS: Comparative morphology of vascular plants. 3rd edition. New York: WH Freeman; 1989.

7. Kubitzki K: Gnetatae. In The Families and Genera of Vascular Plants, vol. I. Pteridophytes and gymnosperms. Edited by Kramer KU, Green PS. Berlin, Heidelberg: Springer-Verlag; 1990:378-391.

8. Yang $Y$ : Ontogeny of triovulate cones of Ephedra intermedia and origin of the outer envelope of ovules of Ephedraceae. Am J Bot 2004, 91:361-368.

9. Anderson JM, Anderson HM, Cleal CJ: Brief history of the gymnosperms: classification, biodiversity, phytogeography and ecology. Strelitzia 2007, 20:1-280.

10. Rydin C, Khodabandeh A, Endress PK: The female reproductive unit of Ephedra (Gnetales): comparative morphology and evolutionary perspectives. Bot J Linn Soc 2010, 163:387-430.

11. Friedman WE: Double fertilization in Ephedra, a non-flowering seed plant: its bearing on the origin of angiosperms. Science 1990, 247:951-954.

12. Friedman WE, Carmichael JS: Double fertilization in Gnetales: implications for understanding reproductive diversification among seed plants. Int J Plant Sci 1996, 157(6 suppl.):S77-S94. 
13. Yang Y, Fu DZ, Wen LH: On double fertilization in Ephedra. Adv Plant Sci 2000, 3:67-74

14. Rudall PJ, Hilton J, Vergara-Silva F, Bateman RM: Recurrent abnormalities in conifer cones and the evolutionary origins of flower-like structures. Trends Plant Sci 2011, 16:151-159.

15. Yang Y, Fu DZ, Wang Q: Origin of flowers: hypotheses and evidence. Acta Bot Boreal-Occident Sin 2004, 24:2366-2380.

16. McCoy SR, Kuehl JV, Boore JL, Raubeson LA: The complete plastid genome sequence of Welwitschia mirabilis: an unusually compact plastome with accelerated divergence rates. BMC Evol Biol 2008, 8:130.

17. Rothwell GW, Crepet WL, Stockey RA: Is the anthophyte hypothesis alive and well? New evidence from the reproductive structures of Bennettitales. Am J Bot 2009, 96:296-322.

18. Doyle JA: Molecular and fossil evidence on the origin of angiosperms. Annu Rev Earth Planet Sci 2012, 40:301-326.

19. Crane PR: Phylogenetic analysis of seed plants and the origin of angiosperms. Ann Missouri Bot Gard 1985, 72:716-793.

20. Doyle JA, Donoghue MJ: Seed plant phylogeny and the origin of angiosperms: an experimental cladistic approach. Bot Rev 1986, 52:321-431.

21. Crane PR, Friis EM, Pedersen KR: The origin and early diversification of angiosperms. Nature 1995, 374:27-33.

22. Doyle JA: Seed plant phylogeny and the relationships of Gnetales. Int J Plant Sci 1996, 157(6 suppl.):S3-S39.

23. Doyle JA: Molecules, morphology, fossils, and the relationship of angiosperms and Gnetales. Mol Phylogen Evol 1998, 9:448-462.

24. Nixon KC, Crepet WL, Stevenson D, Friis EM: A reevaluation of seed plant phylogeny. Ann Missouri Bot Gard 1994, 81:484-533.

25. Friis EM, Crane PR, Pedersen KR, Bengtson S, Donoghue PCJ, Grimm GW, Stampanoni M: Phase-contrast X-ray microtomography links Cretaceous seeds with Gnetales and Bennettitales. Nature 2007, 450:549-553.

26. Friis EM, Pedersen KR, Crane PR: Early cretaceous mesofossils from Portugal and eastern North America related to the BennettitalesErdtmanithecales-Gnetales group. Am J Bot 2009, 96:252-283.

27. Bowe LM, Coat G, dePamphilis CW: Phylogeny of seed plants based on all three genomic compartments: extant gymnosperms are monophyletic and Gnetales' closest relatives are conifers. Proc Natl Acad Sci USA 2000, 97:4092-4097.

28. Hajibabaei M, Xia JN, Drouin G: Seed plant phylogeny: gnetophytes are derived conifers and a sister group to Pinaceae. Mol Phylogen Evol 2006, 40:208-217.

29. Braukmann TWA, Kuzmina M, Stefanović S: Loss of all plastid ndh genes in Gnetales and conifers: extent and evolutionary significance for the seed plant phylogeny. Curr Genet 2009, 55:323-337

30. Rydin C, Korall P: Evolutionary relationships in Ephedra (Gnetales) —with implications for seed plant phylogeny. Int J Plant Sci 2009, 170:1031-1043.

31. Zhong BJ, Yonezawa T, Zhong Y, Hasegawa M: The position of Gnetales among seed plants: overcoming pitfalls of chloroplast phylogenomics. Mol Biol Evol 2010, 27:2855-2863.

32. Price RA: Systematics of the Gnetales: a review of morphological and molecular evidence. Int J Plant Sci 1996, 157(6 suppl.):S40-S49.

33. Huang JL, Giannasi DE, Price RA: Phylogenetic relationships in Ephedra (Ephedraceae) inferred from chloroplast and nuclear DNA sequences. Mol Phylogen Evol 2005, 35:48-59.

34. Maheshwari P, Vasil V: Gnetum. New Delhi: Council of Scientific \& Industrial Research; 1961.

35. Shindo $S$, Ito M, Ueda K, Kato M, Hasebe M: Characterization of MADS genes in the gymnosperm Gnetum parvifolium and its implication on the evolution of reproductive organs in seed plants. Evol Develop 1999, 1:180-190.

36. Shindo S, Sakakibara K, Sano R, Ueda K, Hasebe M: Characterization of a floricaula/leafy homologue of Gnetum parvifolium and its implications for the evolution of reproductive organs in seed plants. Int J Plant Sci 2001, 162:1199-1209.

37. Stapf O: Die Arten der Gattung Ephedra (monograph). Denkschr Kaiserl Akad Wiss Math-Naturwiss Kl 1889, 56:1-112.

38. Florin R: Über einige neue oder wenig bekannte asiatische Ephedra-Arten der Sect. Pseudobaccatae Stapf. Kongl Svensk Vetensk Akad Handl, 3 Ser 1933, 12:264-289.

39. Takaso T: Structural changes in the apex of the female strobilus and the initiation of the female reproductive organ (ovule) in Ephedra distachya L. and E. equisetina Bge. Acta Bot Neerl 1984, 33:257-266.
40. Yang Y: Ontogeny and metamorphic patterns of female reproductive organs of Ephedra sinica Stapf (Ephedraceae). Acta Bot Sin 2001, 43:1011-1017

41. Pilger R: Gymnospermae. In Die Natürlichen Pflanzenfamilien, band 13 Edited by Engler A, Prantl K. Leipzig: Wilhelm Englemann; 1926.

42. Hufford L: The morphology and evolution of male reproductive structures of Gnetales. Int J Plant Sci 1996, 157(6 suppl.):S95-S112.

43. Wang ZQ: A new Permian Gnetalean cone as fossil evidence for supporting current molecular phylogeny. Ann Bot 2004, 94:281-288.

44. Ash SR: Late Triassic plants from the Chinle Formation in northeastern Arizona. Palaeontology 1972, 15:598-618.

45. Ash SR: Dinophyton, a problematical new plant genus from the Upper Triassic of the southeastern United States. Palaeontology 1970, 13:646-663.

46. Krassilov VA, Ash SR: On Dinophyton-protognetalean Mesozoic plant. Palaeontogr Abt B 1988, 208:33-38.

47. Cornet $B$ : The leaf venation and reproductive structures of a late Triassic angiosperm: Sanmiguelia lewisii. Evol Theory 1986, 7:231-309.

48. Friis EM, Crane PR, Pedersen KR: Early flowers and angiosperm evolution. Cambridge: Cambridge University Press; 2011.

49. Cornet B: A new gnetophyte from the late Carnian (Late Triassic) of Texas and its bearing on the origin of the angiosperm carpel and stamen. In Flowering plant origin, evolution, and phylogeny. Edited by Taylor DW, Hickey LJ. New York: Chapman Hall; 1996:32-67.

50. Wu XW, He YL, Mei SW: Discovery of Ephedrites from the Lower Jurassic Xiaomeigou Formation, Qinhai. Acta Palaeobot Palynol Sin 1986, 1:13-21.

51. Li PJ, He YL, Wu XW, Mei SW, Li BY: Early and Middle Jurassic strata and their floras from northeastern border of Qaidam Basin, Qinghai. Nanjing: Nanjing University Press; 1988.

52. Crane PR: The fossil history of the Gnetales. Int J Plant Sci 1996, 157(6 suppl.):S50-S57.

53. Crane PR, Upchurch GR: Drewria potomacensis gen. et sp. nov., an early Cretaceous member of Gnetales from the Potomac Group of Virginia. Am J Bot 1987, 74:1722-1736.

54. Krassilov VA: New floral structure from the Lower Cretaceous of Lake Baikal area. Rev Palaeobot Palynol 1986, 47:9-16.

55. Krassilov VA: Diversity of Mesozoic gnetophytes and the first angiosperms. Paleontol J 2009, 43:1272-1280.

56. Doyle JA, Donoghue MJ: Phylogenies and angiosperm diversification. Paleobiology 1993, 19:141-167.

57. Yang $Y$ : A review on gnetalean megafossils: problems and perspectives. Taiwania 2010, 55:346-354

58. Dilcher DL, Bernardes-de-Oliveira ME, Pons D, Lott TA: Welwitschiaceae from the Lower Cretaceous of northeastern Brazil. Am J Bot 2005, 92:1294-1310.

59. Guo SX, Sha JG, Bian LZ, Qiu YL: Male spike strobiles with Gnetum affinity from the Early Cretaceous in western Liaoning, Northeast China. J Syst Evol 2009, 47:93-102

60. Rydin C, Mohr B, Friis EM: Cratonia cotyledon gen. et sp. nov.: a unique Cretaceous seedling related to Welwitschia. Proc R Soc Lond B 2003, 270 (suppl):S29-S32

61. Yang Y, Wang Q: The earliest fleshy cone of Ephedra from the Early Cretaceous Yixian Formation of Northeast China. PLoS One 2013, 8:e53652.

62. Yang Y, Geng BY, Dilcher DL, Chen ZD, Lott TA: Morphology and affinities of an Early Cretaceous fossil-Ephedra archaeorhytidosperma sp. nov. (Ephedraceae-Gnetopsida). Am J Bot 2005, 92:231-241.

63. Wang X, Zheng SL: Whole fossil plants of Ephedra and their implications on the morphology, ecology and evolution of Ephedraceae (Gnetales). Chin Sci Bull 2010, 55:1511-1519.

64. Cladera G, Fueyo GMD, de Seoane LV, Archangelsky S: Early Cretaceous riparian vegetation in Patagonia, Argentina. Rev Mus Argentino Cienc Nat, N S 2007, 9:49-58.

65. Tao JR, Yang Y: Alloephedra xingxuei gen. et sp. nov., an early Cretaceous member of Ephedraceae from Dalazi Formation in Yanji Basin, Jilin Province of China. Acta Palaeontol Sin 2003, 42:208-215.

66. Liu HM, Ferguson DK, Hueber FM, Li CS, Wang YF: Taxonomy and systematics of Ephedrites cheniae and Alloephedra xingxuei (Ephedraceae). Taxon 2008, 57:577-582.

67. Sun G, Zheng SL, Dilcher DL, Wang YD, Mei SW: Early angiosperms and their associated plants from western Liaoning, China. Shanghai: Shanghai Scientific and Technological Education Publishing House; 2001.

68. Krassilov VA: Early Cretaceous flora of Mongolia. Palaeontogr Abt B 1982, $181: 1-43$ 
69. Akhmetiev MA, Krassilov VA: Recollected proangiosperms and correlation of Upper Mesozoic lacustrine deposits in East Asia. Stratigr Geol Correlation 2002, 10:414-418.

70. Duan SY: The oldest angiosperm - a tricarpous female reproductive fossil from western Liaoning Province, NE China. Sci China Ser D Earth Sci 1998, 41:14-20.

71. Wu SQ: A preliminary study of the Jehol flora from western Liaoning. Palaeoworld 1999, 11:7-57.

72. Wu SQ: Land plants. In The Jehol Fossils: the emergence of feathered dinosaurs, beaked birds and flowering plants. Edited by Chang MM, Chen PJ, Wang YQ, Wang Y, Miao DS. Shanghai: Shanghai Scientific and Technical Publishers; 2003:167-177.

73. Wang $X:$ The dawn angiosperms: uncovering the origin of flowering plants. Berlin: Springer; 2010.

74. Rydin C, Wu SQ, Friis EM: Liaoxia (Gnetales): ephedroids from the Early Cretaceous Yixian Formation in Liaoning, northeastern China. PI Syst Evol 2006, 262:239-265.

75. Yang Y: The nomenclature of fossil Ephedraceae. Taxon 2007, 56:1271-1273.

76. Guo SX, Wu XW: Ephedrites from latest Jurrassic Yixian Formation in western Liaoning, Northeast China. Acta Palaeontol Sin 2000, 39:81-91.

77. Rydin C, Friis EM: A new Early Cretaceous relative of Gnetales: Siphonospermum simplex gen. et sp. nov. from the Yixian Formation of Northeast China. BMC Evol Biol 2010, 10:183.

78. Krassilov VA, Dilcher DL, Douglas JG: New ephedroid plant from the Lower Cretaceous Koonwarra fossil bed, Victoria, Australia. Alcheringa 1998, 22:123-133.

79. Cao ZY, Wu SQ, Zhang PA, Li JR: Discovery of fossil monocotyledons from Yixian Formation, western Liaoning. Chin Sci Bull 1998, 43:230-233.

80. Zheng SL: Plants. In Standard sections of Tuchengzi Stage and Yixian Stage and their stratigraphy, palaeontology and tectonic-volcanic actions. Edited by Wang WL, Zhang H, Zhang LJ, Zheng SL, Yang FL, Li ZT, Zheng YJ, Ding QH. Beijing: Geological Publishing House; 2004:203-225.

81. Rydin C, Pedersen KR, Friis EM: On the evolutionary history of Ephedra: cretaceous fossils and extant molecules. Proc Natl Acad Sci USA 2004, 101:16571-16576.

82. Rydin C, Pedersen KR, Crane PR, Friis EM: Former diversity of Ephedra (Gnetales): evidence from Early Cretaceous seeds from Portugal and North America. Ann Bot 2006, 98:123-140.

83. Hou LH, Zhang JY: A new fossil bird from Lower Cretaceous of Liaoning. Vertebr PalAsiat 1993, 31:217-224.

84. Li PX, Cheng ZW, Pang QQ: The horizon and age of the Confuciusornis in Beipiao, western Liaoning. Acta Geol Sin 2001, 75:1-13.

85. Pearson HHW: Gnetales. London: Cambridge University Press; 1929.

86. Martens P: Les Gnétophytes. Encyclopedia of plant anatomy 12 (2). Berlin: Gebrüder Borntraeger; 1971.

87. Eames A: Relationships of the Ephedrales. Phytomorphology 1952, 2:79-100.

88. Yamada T, Hirayama Y, Imaichi R, Kato M: AINTEGUMENTA homolog expression in Gnetum (gymnosperms) and implications for the evolution of ovulate axes in seed plants. Evol Devel 2008, 10:280-287.

89. Mundry M, Stützel T: Morphogenesis of the reproductive shoots of Welwitschia mirabilis and Ephedra distachya (Gnetales), and its evolutionary implications. Organ Divers Evol 2004, 4:91-108.

90. Leslie A: Shifting functional roles and the evolution of conifer pollenproducing and seed-producing cones. Paleobiology 2011, 37:587-602.

91. Fu DZ: Nageiaceae-a new gymnosperm family. Acta Phytotax $\operatorname{Sin} 1992$, 30:515-528.

92. Fu DZ, Yang QE: A new morphological interpretation of the female reproductive organs in Ginkgo biloba L., with a phylogenetic consideration on gymnosperms. Acta Phytotax Sin 1993, 31:294-296. 309-317.

93. Takaso T, Tomlinson PB: Seed cone and ovule ontogeny in Metasequoia, Sequoia and Sequoiadendron (Taxodiaceae-Coniferales). Bot J Linn Soc 1992, 109:15-37

94. Tomlinson PB, Takaso T, Cameron EK: Cone and ovule development in Libocedrus (Cupressaceae)—Phenological and morphological aspects. Am J Bot 1993, 80:649-659.

95. Yang CY: Ephedraceae. In Flora Xinjangensis, vol. 1. Edited by Yang CY. Urümqi: Xinjiang Science \& Technology \& Hygiene Publishing House; 1993:87-109.
96. Freitag H, Maier-Stolte M: Ephedraceae. In Flora of the Arabian Peninsula and Socotra, vol. 1. Edited by Miller AG, Cope TA. Edinburgh: Edinburgh University Press; 1996:75-80.

97. Stevenson DW: Ephedraceae. In Flora of North America North of Mexico, vol. 2. Edited by Flora of North America Editorial Committee. New York: Oxford University Press; 1993:428-434.

98. Fu LG, Yu YF, Riedl H: Ephedraceae. In Flora of China, vol. 4 Cycadaceae through Fagaceae. Edited by Wu ZY, Raven PR. Beijing: Science Press, and St. Louis: Missouri Botanical Garden; 1999:97-101.

99. Mabberley DJ: Mabberley's plant-book: a portable dictionary of plants, their classification and uses. 3rd edition. New York: Cambridge University Press; 2008.

100. Dumortier B-C: Analyse des familles des plantes :avec l'indication des principaux genres qui s'y rattachent. Ainé : Impr. de J. Casterman; 1829.

101. Miki S: Mesozoic flora of Lycoptera beds in South Manchuria. Bull Mukogawa Women's Univ (Nat Sci) 1964, 12:13-22.

102. Chen PJ: Distribution and spread of the Jehol Biota. Palaeoworld 1999, $11: 1-6$.

103. Ji Q: On the Mesozoic Jehol Biota of China. Geol Rev 2002, 48:290-296.

104. Wang XL, Wang YQ, Zhang FC, Zhang JY, Zhou ZH, Jin F, Hu YM, Gu G, Zhang HC: Vertebrate biostratigraphy of the Lower Cretaceous Yixian Formation in Lingyuan, western Liaoning and its neighboring southern Nei Mongol (Inner Mongolia), China. Vertebr PalAsiat 2000, 38:81-99.

105. Leng Q, Friis EM: Sinocarpus decussatus gen. et sp. nov., a new angiosperm with basally syncarpous fruits from the Yixian Formation of Northeast China. Pl Syst Evol 2003, 241:77-88.

106. Chang MM, Chen PJ, Wang YQ, Wang Y, Miao DS: The Jehol Fossils: the emergence of feathered dinosaurs, beaked birds and flowering plants. Shanghai: Shanghai Scientific and Technical Publishers; 2003.

107. Zhou ZH, Barrett PM, Hilton J: An exceptionally preserved Lower Cretaceous ecosystem. Nature 2003, 421:807-814.

108. Zhou ZH: Evolutionary radiation of the Jehol Biota: chronological and ecological perspectives. Geol J 2006, 41:377-393.

109. Chang SC, Zhang HC, Hemming SR, Mesko GT, Fang Y: Chronological evidence for extension of the Jehol Biota into southern China. Palaeogeogr Palaeoclimat Palaeoecol 2012, 344-345:1-5.

110. Bugdaeva EV, Markevich VS: The age of Lycoptera beds (Jehol Biota) in Transbaikalia (Russia) and correlation with Mongolia and China. In Bernissart dinosaurs and early terrestrial ecosystems. Edited by Godefroit P. Bloomington: Indiana University Press; 2012:452-464.

111. Chen PJ, Wang QF, Zhang HC, Cao MZ, Li WB, Wu SQ, Shen YB: Jianshangou Bed of the Yixian Formation in West Liaoning, China. SCi China Ser D Earth Sci 2004, 34:883-895.

112. Chang SC, Zhang HC, Renne PR, Fang Y: High-precision ${ }^{40} \mathrm{Ar} /{ }^{39} \mathrm{Ar}$ age for the Jehol Biota. Palaeogeogr Palaeoclimat Palaeoecol 2009, 280:94-104.

113. Yabe H, Endô S: Potamogeton remains from the Lower Cretaceous ? Lycoptera beds of Jehol. Proc Imp Acad Tokyo 1935, 11:274-276.

114. Yabe H, Endô S: Strobilus of Schizolepis from the Lycoptera-beds of Jehol. Proc Imp Acad Tokyo 1934, 10:658-660.

115. Gradstein FM, Ogg JG, Schmitz MD, Ogg GM: The Geologic Time Scale 2012, Boston: Elsevier; 2012.

116. Sun YB: Drawing method of the black line chart in botanical scientific illustration. Guihaia 2012, 32:55-60.

117. McNeill J, Barrie FR, Buck WR, Demoulin V, Greuter W, Hawksworth DL, Herendeen PS, Knapp S, Marhold K, Prado J, van Reine WF P'h, Smith GF, Wiersema JH, Turland NJ: International Code of Nomenclature for algae, fungi, and plants (Melbourne Code) adopted by the Eighteenth International Botanical Congress Melbourne, Australia, July 2011. Königstein: Koeltz Scientific Books; 2012.

doi:10.1186/1471-2148-13-72

Cite this article as: Yang et al:: Chengia laxispicata gen. et sp. nov., a new ephedroid plant from the Early Cretaceous Yixian Formation of western Liaoning, Northeast China: evolutionary, taxonomic, and biogeographic implications. BMC Evolutionary Biology 2013 13:72. 